\title{
Training on improving and developing business opportunities for micro, small and medium enterprises (UMKM) through online promotions on social media in the building in kelurahan gedung Johor kecamatan Medan Johor
}

\author{
Aflah $^{1 *}$, Puspa Melati Hasibuan ${ }^{1}$, Erna Herlinda ${ }^{1}$, Rabiatul Syahriah $^{1}$, Boy Laksamana ${ }^{1}$ \\ ${ }^{1}$ Faculty of Law, Universitas Sumatera Utara, Medan, Indonesia \\ *Email: aflah@usu.ac.id
}

\begin{abstract}
Social media is a gathering place for people using internet networks, not infrequently even on social media people who have the same mutual interests and form a community. The presence of these community groups can certainly be a target for business people to promote their products, including products from MSMEs. Promotion through the community on social media can be done through soft selling. Effective and efficient use of social media by business actors as a means of trade promotion requires guidance and direction through training. Therefore, in this community service activity, training was carried out on improving and developing business opportunities for Micro, Small and Medium Enterprises (MSMEs) through online promotions on social media to MSMEs located in Kelurahan Gedung Johor. The method of implementing activities is carried out in the form of counseling and interactive dialogue with participants. The use of social media is carried out effectively by providing the best service to consumers by conveying honestly and in good faith, about the merchandise being promoted, there are no things to hide, this is useful for building the seller's reputation and maintaining the trust given by consumers so that consumers remain loyal to the merchandise products of these MSME entrepreneurs.
\end{abstract}

Keyword: development, MSMEs, promotion, social media.

\begin{abstract}
Abstrak
Media sosial merupakan tempat berkumpulnya orang-orang dengan menggunakan jaringan internet, bahkan tak jarang di media sosial orang yang memiliki kesamaan minat saling dan membentuk suatu komunitas. Hadirnya kelompok komunitas tersebut tentu bisa menjadi sasaran para pelaku bisnis untuk mempromosikan produk mereka termasuk juga produk dari UMKM. Promosi melalui komunitas pada media sosial ini bisa dilakukan secara soft selling. Pemanfaat media sosial secara efektif dan efisien oleh pelaku usaha sebagai sarana promosi perdagangan memerlukan suatu bimbingan dan arahan melalui suatu pelatihan. Oleh karena itu dalam kegiatan pengabdian masyarakat ini dilakukan pelatihan tentang peningkatan dan pengembangan Peluang usaha bagi Usaha Mikro Kecil Menengah (UMKM) melalui promosi secara online di media sosial kepada pelaku UMKM yang berlokasi di Kelurahan Gedung Johor. Metode pelaksanaan kegiatan dilakukan dengan bentuk penyuluhan dan dialog interaktif dengan peserta. Pemanfaatan media sosial dilakukan secara efektif dengan memberikan pelayanan terbaik kepada konsumen dengan menyampaikan secara jujur dan beritikad baik, tentang barang dagangan yang dipromosikan, tidak ada hal-hal yang disembunyikan, hal ini berguna untuk membangun reputasi penjual dan menjaga kepercayaan yang diberikan konsumen sehingga konsumen tetap setia dengan produk dagangan pelaku UMKM tersebut.
\end{abstract}

Kata Kunci: pengembangan, UMKM, promosi, media sosial.

\section{PENDAHULUAN (INTRODUCTION)}

Pembinaan dan pengembangan usaha dengan menumbuhkan jiwa wirausaha dan meningkatkan kemampuan berusaha ke depan, haruslah dilakukan dengan penataan ulang segala aspek, kebijakan dan prosedur dari sistem yang telah diterapkan selama ini baik secara nasional maupun regional dan 
lokal. Berbagai komplikasi kebijakan dan prosedur serta program yang ada harus dipangkas. Bidang usaha difokuskan pada penciptaan produk dan jasa yang diminta pasar baik pasar input maupun pasar output dengan mengandalkan keunggulan kompetitif. Informasi dan komunikasi antar pembina dan yang dibina haruslah lebih tepat guna yang terarah pada permintaan pasar dan proses dalam menjangkau pasar. Rendahnya tingkat penguasaan teknologi dan kemampuan wirausaha di kalangan Usaha Mikro Kecil dan Menengah (UMKM) menjadi issue yang mengemuka saat ini.

Penanaman jiwa wirausaha ini dapat dilakukan dengan memberikan pelatihan wirausaha kepada pelaku UMKM. Penguatan jiwa wirausaha menjadi penting karena persaingan dalam dunia usaha saat ini dan di masa yang akan datang akan sangat ketat. Keadaan demikian dikarenakan semakin terbukanya perdagangan dunia yang ditandai dengan munculnya pasar bebas. Produkproduk dari negara lain, khususnya China dengan bebas masuk ke Indonesia dan menjadi saingan produk dalam negeri dengan jenis yang sama. Tanpa adanya kreativitas dan inovasi usaha, kemampuan bersaing dari UMKM dalam negeri akan rendah yang tentunya akan berakibat pada kemunduran bahkan mengancam kelangsungan UMKM yang bersangkutan. Dengan demikian diperlukan usaha untuk menumbuhkan dan mengembangkan jiwa wirausaha pada pelaku UMKM. Sementara itu tujuan dari pelatihan wirausaha ini bukan untuk mengarahkan masyarakat untuk menjadi pelaku usaha tetapi lebih ditekankan kepada bagaimana masyarakat pada umumnya dan pelaku UMKM pada khususnya dapat pelihat peluang usaha dengan memanfaatkan segala potensi yang dimiliki oleh dirinya serta lingkungan sekitarnya. Disisi lain juga dapat mengidentifikasi permasalahan yang dihadapi sebagai sebuah potensi sehingga tidak menghambat dalam usaha, juga berkaitan dengan unsur yuridisnya yang harus dipahami oleh UMKM seperti keabsahan pendirian usaha yang berkaitan dengan ijin usaha dan perjanjian yang dilakukan dengan pihak lain.

Pada zaman modern ini, perkembangan teknologi dan informasi saat ini tumbuh amat sangat cepat dan pesat. Teknologi informasi yang menjadi sangat popular dan semakin familiar bagi lingkungan masyarakat saat ini adalah media sosial. Di era sekarang ini media sosial berubah dari yang tadinya hanyalah kebutuhan tersier, tapi sekarang seolah-olah sudah bergeser menjadi kebutuhan pokok atau primer bagi semua orang atau masyarakat. Jejaring sosial yang cukup populer dan digunakan oleh masyarakat banyak antara lain facebook, instagram, twitter, whatsapp, telegram, path, line, dan lain-lain. Sehingga tidak jarang para pelaku bisnis memanfaatkan media sosial ini untuk melakukan promosi produk barang atau jasa.

Pemanfaat media sosial secara efektif dan efisien oleh pelaku usaha memerlukan suatu bimbingan dan arahan melalui suatu pelatihan. Oleh karena itu tim pengabdian masyarakat Universitas Sumatera Utara melakukan kegiatan pengabdian dalam bentuk penyuluhan dan pelatihan tentang peningkatan dan pengembangan Peluang usaha bagi Usaha Mikro Kecil Menengah (UMKM) melalui promosi secara online di media sosial kepada pelaku UMKM yang berlokasi di Kelurahan Gedung Johor Kecamatan Medan Johor.

Melalui Pengabdian masyarakat ini tujuan yang ingin dicapai antara lain, meningkatnya wawasan dan pengetahuan UMKM untuk mengembangkan konsep kewirausahaan yang berinovasi dan kreatif, serta bertambahnya pengetahuan pelaku usaha tentang tata cara promosi produk dan usaha dengan memanfaatkan media sosial online secara kreatif yang diharapkan dapat meningkatkan usaha UMKM tersebut.

\section{METODE PELAKSANAAN (METHODS)}

Kegiatan pengabdian dilakukan dengan pelatihan melalui metode ceramah dan simulasi. Peserta pelatihan juga diberi kesempatan untuk berdiskusi melalui tanya jawab kepada nara sumber. Pemetaan akar permasalahan yang dihadapi oleh UMKM selanjutnya dilakukan dengan memberikan 
Aflah et.al. Training on improving and developing business opportunities for micro

pelatihan atau penyuluhan untuk meningkatkan pengetahuan pelaku UMKM tentang pemanfaatan dan penggunaan media sosial online sebagai sarana promosi pada usaha dagangnya

\section{HASIL DAN PEMBAHASAN (RESULT AND DISCUSSION)}

Kelurahan Gedung Johor adalah merupakan salah satu Kelurahan yang berada di wilayah Kecamatan Medan Johor dengan luas 315 hektar yang terdiri atas 13 lingkungan dengan batas-batas wilayah sebagai berikut, sebelah utara berbatas dengan Kelurahan Pangkalan Masyhur Kecamatan Medan Johor, sebelah selatan berbatas dengan Desa Namo Rambe Kecamatan Deli Tua Kabupaten Deli Serdang, sebelah Timur berbatas dengan Sungai Deli dan sebelah barat berbatas dengan Sungai Babura.

Berdasarkan data-data yang dihimpun pada akhir Bulan Desember 2020, Kelurahan Gedung Johor mempunyai susunan penduduk sebagai berikut:

\begin{tabular}{|c|c|c|c|}
\hline NO & LINGKUNGAN & JUMLAH KK & JUMLAH JIWA \\
\hline 1. & Lingkungan I & 480 & 2,488 \\
\hline 2. & Lingkungan II & 391 & 2,285 \\
\hline 3. & Lingkungan III & 440 & 2,414 \\
\hline 4. & Lingkungan IV & 569 & 2,427 \\
\hline 5. & Lingkungan V & 489 & 2,224 \\
\hline 6. & Lingkungan VI & 598 & 2,628 \\
\hline 7. & Lingkungan VII & 506 & 2,522 \\
\hline 8. & Lingkungan VIII & 442 & 2,799 \\
\hline 9. & Lingkungan IX & 527 & 2,610 \\
\hline 10. & Lingkungan X & 495 & 2,928 \\
\hline 11. & Lingkungan XI & 464 & 2,577 \\
\hline 12. & Lingkungan XII & 355 & 1,419 \\
\hline 13. & Lingkungan XIII & 534 & 2,550 \\
\hline & J U M L A H & $\mathbf{6 . 2 9 0}$ & $\mathbf{3 1 . 8 7 1}$ \\
\hline
\end{tabular}

Table 3. Susunan Penduduk

Sarana dan prasarana yang dimiliki di Kelurahan Gedung Johor, antara lain, Pasar Tradisional, Sarana Kesehatan, Rumah Sakit, Klinik, Praktek Dokter, Praktek Bidan, Posyandu, Apotik/Toko Obat, Puskesmas, Sarana Pendidikan (TK, SD, SMP dan SLTA), Sarana Ibadah (Mesjid, Langgar dan Musholla serta Gereja), Sarana Olah Raga (Lapangan Volley, Lapangan Badminton, dan Lapangan Sepak bola). 


\subsection{Usaha Mikro Kecil dan Menengah dan Media Sosial}

Ekonomi kerakyatan adalah sistem ekonomi yang berbasis pada kekuatan ekonomi rakyat. Ekonomi rakyat sendiri adalah sebagai kegiatan ekonomi atau usaha yang dilakukan oleh rakyat secara swadaya mengelola sumberdaya ekonomi apa saja yang dapat diusahakan dan dikuasainya, yang selanjutnya bentuk ekonomi kerakyatan ini terwujud dalam Usaha Mikro, Usaha Kecil dan Menegah (UMKM) yang meliputi sektor pertanian, peternakan, kerajinan, makanan, dan sebagainya, yang ditujukan terutama untuk memenuhi kebutuhan dasarnya dan keluarganya tanpa harus mengorbankan kepentingan masyarakat lainnya.

Ekonomi Kerakyatan merupakan sistem perekonomian yang pelaksanaan kegiatan, pengawasannya, dan hasil dari kegiatan ekonomi dapat dinikmati oleh seluruh masyarakat. Ekonomi kerakyatan juga bisa diartikan sebagai suatu sistem perekonomian yang dibangun pada kekuatan ekonomi rakyat. Ekonomi kerakyatan memberikan kesempatan yang luas bagi seluruh masyarakat dalam berpartisipasi sehingga perekonomian dapat terlaksana dan berkembang secara baik.

Sistem Ekonomi Kerakyatan sebenarnya merupakan sistem ekonomi yang mengacu pada amanat konstitusi nasional, Pancasila dan Undang-Undang Dasar (UUD) Tahun 1945 yang menjadi Landasan Hukum dari Sistem Ekonomi Pancasila.

UMKM merupakan bagian pendukung dari Sistem Ekonomi Kerakyatan yang tersirat dalam Sila Kelima Pancasila. Ekonomi kerakyatan sebagai sebuah sistem mempunyai prinsip-prinsip dasar yang membedakannya dengan sistem ekonomi lainnya.

Prinsip Ekonomi Kerakyatan tertuang dalam Pasal 33 UUD RI Tahun 1945, antara lain, sebagai berikut: 1) Prinsip kekeluargaan. dalam penjelasan UUD 1945 dinyatakan bahwa perekonomian disusun sebagai usaha bersama berdasarkan atas azas kekeluargaan. Prinsip ini merupakan acuan semua badan usaha baik BUMN dan BUMS, BUMD; 2) Prinsip keadilan. Pelaksanaan ekonomi kerakyatan harus bisa mewujudkan keadilan dalam masyarakat. Sistem ini diharapkan dapat memberikan peluang yang sama kepada semua anak bangsa, apakah itu sebagai konsumen, pengusaha maupun sebagai tenaga kerja. Tidak ada perbedaan suku, agama dan gender, semuanya sama dalam lapangan ekonomi; 3) Prinsip pemerataan pendapatan. Masyarakat sebagai konsumen dan pelaku ekonomi harus merasakan pemerataan pendapatan. Kalau selam ini pemerintah terlalu mementingkan pertumbuhan ekonomi yang tinggi teryata itu hanya semu belaka. Pertumbuhan yang tinggi tidak membawa pada pemerataan pendapatan. Pertumbuhan itu hanya dirasakan segelintir masyarakat yang disebut pengusaha besar, sementara mayoritas masyarakat berbeda pada posisi miskin dan melarat; 4) Prinsip keseimbangan antara kepentingan individu dan kepentingan masyarakat. Kegiatan ekonomi harus mampu mewujudkan adanya sinergi antara kepentingan individu dengan kepentingan masyarakat. Pada pasal 27 ayat 2 UUD 1945 menyatakan bahwa tiaptiap warga negara berhak atas pekerjaan dan penghidupan yang layak bagi kemanusiaan. Prinsip kerja sama atau jaringan. Dalam prinsip ini para pelaku ekonomi harus saling membantu dan bekerja sama. Dengan kerja sama tentu berbagai kegiatan usaha kecil akan menjadi kuat dan besar.

Menurut Tambunan, UMKM adalah unit usaha produktif yang berdiri sendiri, yang dilakukan oleh orang perorangan atau badan usaha di semua sektor ekonomi. Kriteria yang digunakan untuk mendefinisikan UMKM terdapat beberapa dalam kategori sebagai berikut: ${ }^{1}$ a) Kategori UMI (usaha mikro) Nilai asetnya paling banyak 50 juta dan Hasil penjualan/tahun Rp 300 juta; b)Kategori UK (usaha kecil) Nilai asetnya lebih dari Rp 50 juta hingga Rp 500 juta dan Hasil penjualan/tahun Rp 300 juta hingga Rp 2,5 miliyar; c) Kategori UM (usaha menengah) Kekayaan bersih lebih dari Rp 500 juta hingga Rp 10 miliyar dan Hasil penjualan/tahun Rp 2,5 miliyar hingga Rp 50 miliyar.

Kategori lain yaitu Usaha Besar (UB) dengan kriteria omzet pertahun yang dimiliki lebih dari 50 (lima puluh) Milyar dan Asset lebih dari 10 (sepuluh) Milyar.

${ }^{1}$ T. Tambunan, Usaha Mikro, Kecil dan Menengah di Indonesia: Isu-Isu Penting, Jakarta, LP3ES, 2012, hal. 11. 
Berdasarkan kategori omzet dan asset yang dimiliki oleh UMKM, dapat diketahui bahwa ternyata kebanyakan usaha yang ada di Indonesia adalah kategori usaha mikro dengan presentase mencapai lebih dari $98 \%$, sedangkan sisanya merupakan usaha kecil, usaha menengah dan sangat sedikit usaha besar di Indonesia yang hanya $0.01 \% .^{2}$

UMKM dari tahun ke tahun terus mengalami perkembangan, jika ditinjau dari perkembangan aktifitas bisnisnya, maka UMKM dapat dikelompokkan dalam beberapa klasifikasi, antara lain, sebagai berikut: ${ }^{3}$ 1) Livelihood Activities, merupakan UMKM yang digunakan sebagai kesempatan kerja untuk mencari nafkah, yang lebih umum biasa disebut sektor informal. Contohnya pedagang kaki lima; 2) Micro Enterprise, merupakan UMKM yangmemiliki sifat pengrajin tetapi belum memiliki sifat kewirausahaan; 3) Small Dynamic Enterprise, merupakan UMKM yang telah memiliki jiwa kewirausahaan dan mampu menerima pekerjaan subkontrak dan ekspor; dan 4) Fast Moving Enterprise, merupakan UMKM yang telah memiliki jiwa kewirausahaan dan akan melakukan transformasi menjadi usaha besar (UB).

Usaha kecil di Indonesia mempunyai potensi yang besar untuk dikembangkan karena pasar yang luas, bahan baku untuk produksi yang mudah didapat serta sumber daya manusia yang besar merupakan variabel pendukung perkembangan dari usaha kecil tersebut, akan tetapi perlu dicermati beberapa hal seiring perkembangan usaha kecil rumahan seperti: perkembangan usaha harus diikuti dengan pengelolaan manajemen yang baik, penguasaan ilmu pengetahuaan akan menunjang keberlanjutan usaha tersebut, mengelola sistem produksi yang efisien dan efektif, serta melakukan terobosan dan inovasi yang menjadikan pembeda dari pesaing merupakan langkah menuju keberhasilan dalam mengelola usaha tersebut.

Secara umum, sektor usaha UMKM ini memiliki karakteristik seperti Sistem administrasi pembukuan yang relatif sederhana dan cenderung tidak mengikuti kaidah admistrasi pembukuan standar, margin usaha yang cenderung tipis mengingat persaingan yang sangat tinggi, Modal terbatas, Pengalaman menejerial dalam mengelola perusahaan masih sangat terbatas, dan skala ekonomi yang terlalu kecil sehingga sulit mengharapkan untuk mampu menekan biaya mencapai titik efisieni jangka panjang, Kemampuan pemasaran dan negosiasi serta diversifikasi pasar sangat terbatas. Karakteristik yang dimiliki oleh usaha mikro menyiratkan adanya kelemahan-kelemahan yang sifatnya potensial terhadap timbulnya masalah. Hal ini menyebabkan berbagai masalah internal terutama yang berkaitan dengan pendanaan yang tampaknya sulit untuk mendapatkan solusi yang jelas. ${ }^{4}$

Usaha yang dilakukan oleh pelaku UMKM telah menunjukkan peranannya dalam perekonomian nasional, tetapi UMKM sendiri masih juga menghadapi berbagai hambatan. Hambatan dan kendala yang dihadapi para pelaku UMKM dalam meningkatkan kemampuan usaha sangat kompleks dan meliputi berbagai aspek yang mana satu dengan yang lainnya saling berkaitan antara 3 lain: kurangnya permodalan baik jumlah maupun sumbernya, kurangnya kemampuan manajerial dan keterampilan beroperasi serta tidak adanya bentuk formal dari perusahaan, lemahnya organisasi dan terbatasnya pemasaran. Disamping itu terdapat juga persaingan yang kurang sehat dan desakan ekonomi sehingga mengakibatkan ruang lingkup usaha menjadi terbatas. Beragamnya hambatan dan kendala yang dihadapi UMKM, tampaknya masalah permodalan masih merupakan salah satu faktor kritis bagi UMKM, baik untuk pemenuhan kebutuhan modal kerja maupun modal investasi dalam pengembangan usaha.

Menghadapi era globalisasi ditambah lagi terjadinya masa pandemic Covid 19 pada tahun 2020 ini, berdampak kepada penurunan pendapatan bahkan beberapa UMKM sempat mengalami keterpurukan usahanya. Hal ini disebabkan terjadinya penurunan daya beli masyarakat dan sebagian konsumen juga mulai beralih melakukan jual beli secara online dengan berbelanja 
kebutuhan yang bisa dilakukan dari rumah untuk menghindari penularan wabah covid 19 ini. Dengan adanya sistem jual beli secara online maupun perdagangan dengan menggunakan teknologi elektronik (e-commerce), UMKM bisa untuk mencoba meningkatkan dan mengembangkan kembali usahanya baik dari jumlah pengusahanya, ataupun jumlah pendapatannya bahkan jenis usaha yang makin kreatif. Salah satunya dengan memanfaatkan media sosial secara online sebagai sarana promosi.

Pada saat ini terdapat dua jenis pemasaran, yaitu secara Offline Marketing dan secara Online Marketing. Kedua jenis pemasaran tersebut memiliki arti yang berbeda dan fungsinya juga berbeda. Offline Marketing, merupakan pemasaran tradisional yang dilakukan dengan mencari pelanggan atau klien melalui pertemuan secara langsung berhadapan dengan mereka yang mungkin tertarik menjadi pelanggan atau klien. Pemasaran yang lain menggunakan situs web sebagai media pemasaran yang dikenal sebagai online marketing. Pemanfaatan social media merupakan salah satu contoh online marketing. ${ }^{5}$

Pada Offline Marketing, untuk melakukan promosi, memerlukan biaya yang tidak sedikit. Hal ini dikarenakan para pebisnis, memerlukan memasang iklan, baik itu di media cetak maupun media elektronik. Disamping itu mereka juga harus memasang iklan dengan menggunakan banner, spanduk maupun billboard. Untuk UMKM yang baru mulai merintis tentunya merasa berat mengeluarkan dana untuk memasang iklan dengan biaya yang besar ini. Sedangkan pada Online Marketing, strategi pemasaran dan promosi melalui dapat dilakukan melalui Media Sosial, hal ini menjadi solusi untuk menghindari biaya promosi yang tinggi. Karena dengan Media Sosial, promosi dapat langsung dilakukan oleh produsen atau pemilik UKM tanpa melalui pihak ke tiga.

Online marketing telah merubah beberapa UKM yang telah memanfaatkan Media Sosial, karena mereka telah mampu mengurangi beban biaya promosi yang sangat besar untuk mengenalkan dan memasarkan produk layanan yang ditawarkan.

Media sosial bukan alat yang baru karena alat ini telah ada sejak manusia saling mengadakan interaksi dengan orang lain di dunia ini dan dinamakan social network. Hanya pada masa modern ini, jaringan sosial diwujudkan dalam bentuk teknologi digital, yaitu online social networking websites seperti: Twitter, Facebook, dan MySpace yang mempunyai dampak signifikan terhadap kehidupan pribadi dan memungkinkan individu-individu mudah untuk berkomunikasi, membagi informasi dan membentuk komunitas secara online. ${ }^{6}$

Salah satu kelebihan media sosial adalah memiliki banyak potensi untuk kemajuan suatu usaha. ${ }^{7}$ Media sosial dapat digunakan untuk melakukan komunikasi dalam bisnis, membantu pemasaran produk dan jasa, berkomunikasi dengan pelanggan dan pemasok, melengkapi merk, mengurangi biaya dan untuk penjualan on line.

Setelah tahun 2015, dengan hadirnya media sosial Whatsapp, penggunaan media tersebut sebagai alat jaringan sosial dapat meningkatkan hubungan kekeluargaan ${ }^{8}$ dan media edukasi. ${ }^{9}$

Media sosial juga mempunyai tujuh fungsi potensial dalam bisnis yaitu mengidentifikasi pelanggannya, mengadakan komunikasi timbal balik, membagikan informasi untuk dapat mengetahui obyek yang disukai pelanggan, kehadiran pelanngan, hubungan antar pelanggan 
berdasarkan lokasi dan pola interaksi, reputasi perusahaan di mata pelanggan dan membentuk kelompok antar pelanggan. ${ }^{10}$

Beberapa bentuk media sosial yang dikenal pada saat ini antara lain, sebagai berikut: ${ }^{11}$ 1) Social Networks atau disebut dengan istilah jejaring sosial merupakan jenis media sosial yang paling umum banyak dikenal dan paling banyak digunakan saat ini, berikut beberapa social networks yang paling banyak digunakan saat ini yaitu, YouTube, Facebook, Twitter, Instagram, WhatsApp, Google Plus, Pinterest, dan lain-lain; 2) Situs forum dan komunitas online umumnya dibangun oleh perorangan atau kelompok yang memiliki minat pada bidang tertentu. Para pengguna forum tersebut dapat juga melakukan diskusi ataupun chatting dan cara memposting tentang topik yang berkaitan dengan minat serta hobby mereka. Beberapa contoh komunitas online, antara lain, Kaskus.co.id, Ads.id, Brainly.co.id dan Indowebster.com. 3) Situs blog juga termasuk dalam kategori media sosial karena memungkinkan pemilik blog dan pembacanya untuk berinteraksi. Umumnya blog dibuat berdasarkan minat atau keahlian si pemilik blog dan konten di dalamnya dapat mempengaruhi banyak orang. Beberapa contoh situs blog yaitu, dosenpintar.com, rumus.co.id dan contohsoal.co.id; 4) Social Bookmark. Disain dari social bookmarking awalnya merupakan sebagai wadah bagi para pengguna internet untuk bookmark alamat website yang disukai pengguna, tetapi pada saat ini pengguna situs social bookmark mulai berkurang dikarenakan beberapa website ini disalahgunakan untuk kegiatan spam para blogger. Beberapa contoh situs social bookmark yang popular, antara lain, Reddit, Slashdot, Diigo.com, dan Scoop.it.

Media sosial dapat dikenali melalui beberapa ciri-ciri yang dimilikinya, antara lain, sebagai berikut: ${ }^{12}$ 1) Partisipasi Pengguna. Semua media sosial mengajak semua penggunanya untuk dapat berperan serta memberikan umpan balik terhadap sesuatu pesan ataupun konten di media sosial. Pesan yang dikirimkan bisa diterima ataupun dibaca oleh banyak orang; 2) Adanya Keterbukaan. Sebagian besar media sosial membagikan kesempatan untuk penggunanya untuk membagikan komentar, melakukan voting, berbagi, dan lain- lain. Pengiriman pesan dapat dilakukan dengan bebas tanpa harus melalui Gatekeeper; 3) Adanya Perbincangan. Mayoritas media sosial membolehkan adanya interaksi terhadap sesuatu konten, baik itu dalam wujud respon maupun pembicaraan antar penggunanya. Serta penerima pesan bebas menentukan kapan melaksanakan interaksi terhadap pesan tersebut; 4) Keterhubungan. Lewat media sosial, para penggunanya bisa tersambung dengan pengguna yang lain lewat sarana tautan (link) serta sumber data yang lain. Proses untuk pengiriman sebuah pesan ke suatu media sosial juga lebih cepat dibandingkan dengan media yang lain membuat informasi banyak terhubung di dalam satu media sosial.

Tujuan dari media sosial antara lain, yaitu sebagai aktualisasi diri. Sebagian besar pengguna menjadikan media sosial sebagai tempat untuk aktualisasi diri. Mereka menunjukkan bakat serta keunikan di media sosial sehingga bisa dilihat banyak orang.

Media sosial juga bisa digunakan untuk membentuk komunitas. Komunitas online sangat mudah untuk dilihat melalui web forum ataupun di web social network yang lain. Media sosial jadi wadah tempat berkumpulnya masyarakat online yang mempunyai atensi yang sama untuk saling berbicara serta bertukar data ataupun pendapat.

Media sosial juga berfungsi penting dalam aktivitas menjalin hubungan personal dengan orang lain secara individu. Terdapat banyak sekali pengguna media sosial yang menemukan pendamping hidup, sahabat, rekan bisnis, di media sosial.

Tujuan yang tidak kalah pentingnya yaitu media sosial ini dapat menjadi media pemasaran dalam Bisnis online. Pengguna media sosial yang jumlahnya sangat banyak pasti saja jadi tempat yang sangat potensial buat memasarkan produk ataupun dagangan dari pelaku UMKM. 


\subsection{Pelaksanaan Pelatihan}

Pengabdian kepada masyarakat yang diselenggarakan oleh tim pengabdian dari Universitas Sumatera Utara dalam bentuk penyuluhan dan pelatihan.

Pelatihan dilaksanakan dengan peserta pelatihan adalah pelaku UMKM yang berdomisili di lingkungan Kelurahan Gedung Johor Medan. Karena pelaksanaan pelatihan dilakukan pada masa pandemic sehingga pelatihan harus dilaksanakan dengan mematuhi protocol Kesehatan dan social distancing. Pelaku UMKM dalam pelatihan ini adalah pemilik dengan jenis usaha dagang. Bidang usaha dagang fokusnya adalah dagang makanan dan minuman, pedagang kue, yang menerima pesanan kue kotak dan nasi kotak. Sebagian besar usaha dagang yang dilakukan sudah berjalan sekitar 2, 3 dan 5 tahun.

Pelatihan tentang Peningkatan dan Pengembangan Peluang Usaha bagi UMKM melalui Promosi secara online di Media Sosial di Kelurahan Gedung Johor dilakukan dengan metode ceramah dan diskusi interaktif. Dalam diskusi interaktif, peserta diberikan beberapa pertanyaan, antara lain, sebagai berikut:

Apakah peserta sudah mempunyai akun media sosial. Respon seluruh peserta pelatihan menjawab mereka sudah mempunyai akun media sosial. Pertanyaan selanjutnya yaitu, jenis media sosial apakah yang dimiliki oleh pelaku UMKM peserta pelatihan. Jawaban yang diperoleh, 90 persen peserta menjawab bahwa mereka memiliki akun WhatsApp dan Facebook, sisanya 10 persen menjawab mempunyai akun WhatsApp, Facebook, Instagram dan Youtube dan tidak ada peserta yang memiliki akun twitter.

Pertanyaan ketiga yang disampaikan, yaitu, apakah para pelaku UMKM ini sudah pernah menggunakan akun media sosialnya masing-masing untuk melakukan promosi barang dagangannya. Seluruh peserta menjawab bahwa mereka ada menggunakan media sosial untuk promosi dagang usahanya.

Facebook dan WhatsApp merupakan media sosial yang paling banyak digunakan untuk sarana promosi dagang para peserta ini. Hal ini karena Facebook dan WhatsApp dianggap sebagai media sosial yang paling efektif karena banyak penggunanya. Facebook memiliki kelebihan dapat dilihat banyak orang dan cepat berinteraksi dengan orang banyak. Whatsapp memiliki kelebihan kemudahan dalam menggunakan, dan mudah dalam menyebarkan gambar dan video.

Alasan lain yaitu, dengan menggunakan Facebook dan WhatsApp, para pelaku UMKM, dapat saling berinteraksi antara pelaku UMKM dengan konsumen (masyarakat). Pemilik UMKM dapat dengan mudah memasukkan semua informasi tentang produknya. Selain itu para konsumen dapat langsung memberikan respon terhadap produk yang dijual tersebut. Sehingga hubungan mempermudah komunikasi dalam mempromosikan produk mereka.

Media sosial dalam bentuk aplikasi Twitter dan YouTube belum pernah digunakan oleh seluruh peserta. Pemanfaatan market place juga belum pernah digunakan oleh seluruh peserta. Sebagian besar dari UMKM secara rutin memperbaharui (update) informasi yang ditampilkan di media sosial setiap hari, tetapi ada juga peserta yang hanya memperbaharui informasi pada media sosialnya hanya sebulan sekali bahkan ada yang hanya memberi informasi baru jika ada pesanan dari konsumen. Dalam penggunaan media sosial ini, peserta UMKM memilih media sosial yang tanpa berbayar. Peserta UMKM hanya mengalokasikan dana untuk pembelian kuota yang berkisar Rp. 100.000.- (Seratus Ribu Rupiah) sampai Rp. 200.000.- (Duaratus Ribu Rupiah) perbulannya untuk pengelolaan media sosial sebagai informasi dan komunikasi kepada konsumennya.

Pertanyaan berlanjut, mengenai pengetahuan peserta tentang pentingnya merek pada usaha dagang dan barang dagangannya serta regulasi tentang pemanfaatan media online sebagai sarana promosi dagangnya.

Jawaban atas pertanyaan ini cukup beragam, antara lain: 1) Pelaku UMKM menjawab bahwa mereka mempunyai merek tetapi mereknya tidak terdaftar; 2) Pelaku UMKM ada juga yang 
menjawab belum mempunyai merek sama sekali baik merek usaha maupun merek dagangnya; 3 ) Untuk regulasi dan ketentuan peraturan perundang-undangan baik tentang merek dan regulasi tentang infomasi dan transaksi elektronik, 70 persen menjawab mengetahui tentang peraturan tersebut tapi tidak memahami substansinya dengan baik. Sedangkan yang 20 persen lagi menjawab tidak mengetahui peraturan tersebut.

Setelah mendengar jawaban dari peserta, tim pengabdian kepada masyarakat merespon dengan memberikan penyuluhan tentang tata cara menggunakan media sosial yang baik dan benar sesuai dengan ketentuan peraturan hukum yang berlaku.

Beberapa informasi disampaikan kepada pelaku UMKM, bahwa ketika menggunakan media sosial sebagai sarana promosi, ada beberapa hal yang harus diperhatikan, antara lain, sebagai berikut: 1) Berikan pelayanan terbaik kepada konsumen dengan menyampaikan secara jujur dan beritikad baik, tentang barang dagangan yang dipromosikan, tidak ada hal-hal yang disembunyikan, hal ini berguna untuk membangun reputasi penjual dan menjaga kepercayaan yang diberikan konsumen sehingga konsumen tetap setia dengan produk dagangan pelaku UMKM tersebut; 2) Sebaiknya pelaku UMKM memiliki merek yang terdaftar, hal ini untuk menghindari adanya peniruan dari UMKM lain yang berbisnis dalam jenis perdagangan yang sama, sehingga konsumen dapat dengan mudah membedakan kualitas barang dengan merek yang digunakan pelaku usaha tersebut; 3) Peniruan merek oleh pelaku UMKM secara langsung maupun tidak langsung dapat merugikan bagi pelaku UMKM, apalagi jika barang yang ditiru dijual dengan harga yang lebih murah; 4) Promosi dagang dengan media sosial online juga harus tetap memperhatikan etika berbisnis, pelaku UMKM jangan pernah menggunakan video atau foto yang sudah pernah diunggah oleh orang lain di internet, jadi pelaku UMKM harus mampu menggali kreatifitasnya dalam mendisain ganbar, foto atau video dalam promosi tersebut; 5) Pelaku UMKM juga sebaiknya berhati-hati dalam sistem pembayaran yang dipilih dan dilakukan, karena tidak tertutup kemungkinan bahwa konsumen atau pembeli ingin melakukan tindak penipuan; dan 6) Kepercayaan harus dibangun secara terus menerus oleh pelaku UMKM terhadap konsumen ataupun calon pembeli, karena banyak juga konsumen yang merasa enggan dan merasa khawatir untuk bertransaksi secara online karena banyak juga di dalam media sosial terjadi penipuan. Oleh karena itu terkadang penjual dan pembeli merasa takut untuk bertransaksi kekhawatiran ini terkait transfer dana dan pengiriman barang.

Melalui pelatihan ini, diharapkan pelaku UMKM mampu mengelola dengan lebih baik penggunaan media sosial untuk sarana promosi dagang. Sehingga media sosial ini bisa memberikan dampak positif pada kenaikan jumlah transaksi penjualan yang sekaligus berdampak pada kenaikan pendapatan.

\section{KESIMPULAN (CONCLUSION)}

Peningkatan produktifitas pelaku usaha UMKM dapat dilakukan melalui promosi secara online di Media Sosial. Pemanfaatan media sosial dilakukan secara efektif dengan memberikan pelayanan terbaik kepada konsumen dengan menyampaikan secara jujur dan beritikad baik, tentang barang dagangan yang dipromosikan, tidak ada hal-hal yang disembunyikan, hal ini berguna untuk membangun reputasi penjual dan menjaga kepercayaan yang diberikan konsumen sehingga konsumen tetap setia dengan produk dagangan pelaku UMKM tersebut.

Pengembangan peluang usaha UMKM dengan pemanfaatan media sosial secara online merupakan cara yang paling efektif dan efisien dalam memangkas biaya promosi karena pelaku usaha dapat menyebarluaskan informasi tentang barang dagangnya kepada konsumen dengan biaya yang relatif murah.

\section{UCAPAN TERIMAKASIH (ACKNOWLEDGMENTS)}


Aflah et.al. Training on improving and developing business opportunities for micro

Pengabdian kepada masyarakat yang dilaksanakan di Kelurahan Gedung Johor Medan Johor ini dapat terselenggara karena bantuan banyak pihak. Oleh karena itu, kami mengucapkan terima kasih kepada semua pihak yang telah membantu dalam proses pelaksanaan pengabdian kepada masyarakat ini, antara lain: Lembaga Pengabdian Pada Masyarakat Universitas Sumatera Utara yang telah mendanai kegiatan ini, Sesuai dengan Surat Perjanjian Penugasan Pelaksanaan Pengabdian Kepada Masyarakat Program Dosen Mengabdi Tahun Anggaran 2020 Nomor: 754/UN5.2.3.2.1/PPM/2020 Tanggal 25 September 2020, Lurah Gedung Johor, anggota dan enumerator Tim Pengabdian Masyarakat serta pelaku UMKM di lingkungan kelurahan Gedung Johor.

\section{DAFTAR PUSTAKA (REFERENCES)}

Alsanie, S. Ibrahim, May. (2015). "Social Media (Facebook, Twitter, Whatsapp) Used, and it's Relationship with the University Students Contact with their Families in Saudi Arabia," Univers. J. Psychol., vol. 3, no. 3, pp. 69-72.

Anggraini, Vita, (2020). Media Sosial: Pengertian, Jenis, Fungsi Dan Tujuan, Posted on 25 June 2020, https://dosenpintar.com/pengertian-media-sosial/, diakses pada 06 Desember 2020.

Anoraga. Pandji, (2010). Ekonomi Islam Kajian Makro dan Mikro. Yogyakarta, PT. Dwi Chandra Wacana, hal. 32.

Baker, D. N. Buoni, M. Fee, and C. Vitale, (2011). "Social networking and its effects on companies and their employees," Retrieved November., vol. 15, p. 2011.

Muda, (2018). Klasifikasi UMKM, “Kategori Manakah Usahamu?”, diunggah tanggal 9 April 2018 in Entrepreneur, https://www.4muda.com/klasifikasi-umkm-kategori-manakah-usahamu/, diakses 6 Desember 2020.

Irianto, Aloysius Bagas Pradipta, (2015). "Pemanfaatan Media Sosial untuk meningkatkan Market Share UKM". Jurnal Teknomatika, Vol. 8, No. 1

Miller, R and N. Lammas, (2010). "Social media and its implications for viral marketing," Asia Pac. Public Relat. J., vol. 11, no. 1, pp. 1-9.

Susilo, A. (2014). Exploring Facebook and Whatsapp as supporting social network applications for English learning in higher education.

Smits, M. and S. Mogos, (2013), “The Impact of Social Media On Business Performance.," in ECIS, p. 125.

Tambunan, T. (2012). Usaha Mikro, Kecil dan Menengah di Indonesia: Isu-Isu Penting, Jakarta, LP3ES, hal. 11. 